\title{
В.А. Лучин*
}

Тихоокеанский океанологический институт им. В.И. Ильичева ДВО РАН, 690041, г. Владивосток, ул. Балтийская, 43

\section{ВНУТРИГОДОВАЯ ИЗМЕНЧИВОСТЬ ПАРАМЕТРОВ ВЕРХНЕГО КВАЗИОДНОРОДНОГО СЛОЯ ОХОТСКОГО МОРЯ}

Использована глубоководная океанографическая информация, полученная из всех доступных источников (111 944 станции за период с 1931 по 2014 г.). Нижняя граница верхнего квазиоднородного слоя (ВКС) на каждой станции была определена по вертикальным распределениям температуры воды. Средние многолетние месячные параметры ВКС были получены с шагом $0,5^{\circ}$ по широте и долготе. Нижняя граница ВКС в Охотском море с мая по октябрь не выходит за пределы 5-25 м (с максимумами в динамически активных районах моря). Максимального развития ВКС достигает в период с декабря по апрель. Поля температуры ВКС Охотского моря группируются в два существенно различающихся между собой типа пространственного распределения. С декабря по апрель для ВКС характерно зимнее распределение температуры с максимальными и положительными значениями в проливах Курильской гряды. С июня по сентябрь в полях температуры ВКС выделяется летний тип пространственного распределения (с пониженными значениями температуры в динамически активных зонах Охотского моря). В мае и октябре-ноябре наблюдаются промежуточные ситуации распределения температуры в ВКС. Средние многолетние месячные поля солености ВКС в течение года сохраняют свои крупномасштабные особенности и являются хорошими индикаторами существующей системы течений и процессов в деятельном слое Охотского моря.

Ключевые слова: Охотское море, верхний квазиоднородный слой, температура и соленость воды, течения, речной сток, вертикальное перемешивание.

DOI: 10.26428/1606-9919-2018-195-170-183.

Luchin V.A. Intra-annual variability of the mixed layer parameters in the Okhotsk Sea // Izv. TINRO. - 2018. - Vol. 195. - P. 170-183.

All available oceanographic data for the deep-water part of the Okhotsk Sea, in total 111,944 stations collected in 1931-2014, are analyzed after removing the duplicate and lowquality ones. The mixed layer depth is determined on the water temperature profile for each station and monthly mean values of temperature and salinity in the mixed layer are calculated for the $0.5^{\circ}$-size grid. In May-October, the mixed layer depth varies within the range 5-25 m, with the highest values in the areas with active water dynamics. On the contrary, the mixed layer is much deeper in December-April when its thickness exceeds 40-60 meters and even reaches 100-120 m in the central Kuril Straits. Two types of temperature distribution change annually within the mixed layer in the Okhotsk Sea: the winter pattern with higher (positive) temperature at Kuril Islands occurs in December-April and the summer pattern is formed in June-September and is distinguished by spots of lower temperature in the dynamically active areas with strong tidal and non-tidal currents (Kuril Straits, Kashevarov Bank, entrance to the Shelikhov Bay, Shantar Islands vicinity, northeastern shelf of Sakhalin Island). Transition

* Лучин Владимир Александрович, доктор географических наук, ведущий научный сотрудник, e-mail:vluchin@poi.dvo.ru.

Luchin Vladimir A., D.Sc., leading researcher, e-mail:vluchin@poi.dvo.ru. 
patterns of the temperature distribution are observed in May, October, and November. Largescale patterns of salinity distribution within the mixed layer are permanent throughout a year and indicate prevailing currents and other processes in the upper layer of the Okhotsk Sea. The maximum salinity is observed in the southern Okhotsk Sea, whereas the lower salinity values are usual for the coastal waters (except the coasts of Kuril Islands) affected to the river runoff.

Key words: Okhotsk Sea, mixed layer, water temperature, salinity, sea current, river runoff, vertical mixing.

\section{Введение}

Охотское море - один из высокопродуктивных районов Мирового океана с традиционными районами промысла минтая, сельди, тихоокеанских лососей, крабов и других видов рыб и беспозвоночных. В нем сосредоточено около 58 \% общей биомассы макрофауны и около 62 \% биомассы рыб дальневосточных морей России (Шунтов, 2016). Важность изучения условий обитания биологических объектов как одного из элементов экосистемных исследований неоднократно подчеркивалась предыдущими исследователями (Гершанович, Муромцев, 1982; Шунтов, 1986; Радченко и др., 1997; Дулепова, 2005).

Верхний квазиоднородный слой (ВКС) формируется в результате термического и динамического взаимодействия на границе океана и атмосферы (поверхностного прогрева/охлаждения, ветро-волнового перемешивания, внутриводного бокового и вертикального обмена и т.д.). Он является одной из самых важных океанских переменных для климата Земли. Основные океанские биологические и химические процессы, которые играют важную роль в климате Земли, также происходят в смешанном слое (Falkowski et al., 1998). Исследования концентрации хлорофилла, рыбных ресурсов, обмена $\mathrm{CO}_{2}$ на границе океан-атмосфера свидетельствуют о необходимости более точных данных о параметрах BKC (Oh et al., 1999; Yamada et al., 2004; Jo et al., 2007; Jang et al., 2011).

К настоящему времени имеется ограниченное число исследований, однозначно направленных на расчет и анализ пространственно-временной изменчивости параметров ВКС Охотского моря. Так, П.В. Ушаков (1949), взяв за основу распределение бентических группировок и дополнительно привлекая вертикальное распределение температуры, солености и кислорода, определил поверхностный слой летнего прогрева (от 0 до 30-50 м). К.В. Морошкин (1966) на основе обобщения многолетних данных установил, что толщина верхнего квазиоднородного слоя летом не превышает 10-25 м, а осенне-зимняя конвекция достигает глубины 100-300 м. Более того, привлекая данные по распределению устойчивости, он показал, что конвекция может достигать глубины не более 250-300 м, а не 1000-1500 м, как у А.К. Леонова (1960). Согласно Kitani (1973), летняя поверхностная вода в море имеет нижнюю границу на горизонтах 20-50 м. В.А. Лучин и В.М. Лаврентьев (1998) по многолетним данным выделили в глубоководной части Охотского моря поверхностную водную массу с нижней границей на 25-50 м. Г.В. Хен с соавторами (2002) представили изменчивость параметров ВКС в Охотском море для аномально холодного 2000 г. и аномально теплого 1997 г. Сравнительный анализ прогрева верхнего слоя в сахалино-курильском районе (для экстремальных 1997 и 2000 гг.) представил Н.С. Ванин (2002).

Необходимо отметить отсутствие ежемесячных климатологических оценок параметров ВКС для всей акватории Охотского моря, несмотря на то что это важная информация для понимания пространственно-временной изменчивости биогеохимических процессов в море и один из входных параметров при реализации численных моделей. В основном это следствие того, что имеющиеся данные океанографических наблюдений, характеризующие деятельный слой моря, находятся в различных (не всегда доступных) источниках, имеют различные форматы и структуру их хранения, а также распределены неравномерно во времени и в пространстве. Отметим также, что параметры верхнего квазиоднородного слоя, полученные по данным отдельных разрезов или съемок локальных акваторий, не в полной мере отражают весь спектр природных изменений и сезонной изменчивости этого важного структурного элемента вариаций состояния вод моря. 
Цель настоящей работы - показать внутригодовую изменчивость параметров верхнего квазиоднородного слоя Охотского моря с использованием наиболее полного исторического массива океанографических данных.

\section{Материалы и методы}

Для расчета параметров ВКС сформирован массив океанологической информации Охотского моря, который включает все доступные данные организаций России, Японии и США. Преобладающая часть данных наблюдений получена учреждениями России (Росгидромет, ТИНРО-центр, Гидрографическая Служба ТОФ, Академия Наук). В массиве присутствуют станции с батометрическими наблюдениями (с разреженной дискретностью по вертикали, которая равна или близка к стандартным горизонтам), а также батитермографные и CTD-наблюдения, у которых более высокое разрешение измеряемых параметров по вертикали. Вначале была проведена процедура исключения дублей станций, что неизбежно при обобщении массового материала наблюдений, взятого из различных источников. Затем отбраковывались недостоверные значения характеристик с применением статистических методов и региональных особенностей моря. После исключения дублирующих станций и недостоверной информации в результирующем океанографическом массиве осталось 111944 станции за период с 1931 по 2014 г. Однако станций с одновременным определением температуры и солености оказалось существенно меньше - 81435.

Наиболее часто для определения параметров ВКС используют вертикальные распределения плотности или температуры морской воды (Thomson, Fine, 2003; Lorbacher et al., 2006; Holte, Talley, 2009), а также различные пороговые критерии (Каra et al., 2000; Ohno et al., 2004; D’Ortenzio et al., 2005; Oka et al., 2007; Dong et al., 2008).

В настоящей работе верхний квазиоднородный слой идентифицировался как слой воды с относительно однородным распределением температуры по вертикали. Его нижняя граница на каждой станции была определена по вертикальным распределениям температуры воды. На каждой океанографической станции нижняя граница ВКС рассчитывалась с использованием следующих критериев.

1. Температура воды в ВКС отличалась не более чем на 5 или $10 \%$ от температуры поверхности моря. Эти условия применялись для станций, выполненных в теплый период года (с июня по октябрь). Сравнение полученных результатов (расчеты для критериев 5 и 10 \%) показало их хорошую согласованность как по глубине положения нижней границы ВКС, так и по средним значениям температуры и солености воды в нем. Поэтому окончательные расчеты параметров ВКС для периода с июня по октябрь на каждой станции выполнялись с использованием 10 \% критерия.

2. Для периода с ноября по май критериями для определения нижней границы ВКС являлись фиксированные значения температуры воды, равные 0,$1 ; 0,3 ; 0,5 ; 1,0$ и $1,5^{\circ} \mathrm{C}$. Это связано с тем, что зимой в районах, где температура воды близка к нулевым значениям, при использовании критерия 5 или $10 \%$ от поверхностных значений температуры воды можно получить нереально малую глубину нижней границы ВКС (это актуально даже при незначительных «выбросах» на вертикальных профилях температуры). Более того, в холодный период года и ранней весной верхняя часть профилей температуры может трансформироваться при прохождении циклонов (приносящих сравнительно холодные или теплые воздушные массы на исследуемую акваторию), а также усиливающих ветро-волновое перемешивание верхнего слоя морских вод. Проведенные эксперименты показали близкие результаты при использовании критериев 0,$1 ; 0,3$ и $0,5{ }^{\circ} \mathrm{C}$. При использовании критериев 1,0 и $1,5^{\circ} \mathrm{C}$ были получены нереально большие значения нижней границы ВКС (до 1000 м). Поэтому окончательные расчеты параметров ВКС на каждой станции выполнялись с использованием средних параметров по трем расчетам (с использованием критериев 0,$1 ; 0,3$ и $0,5{ }^{\circ} \mathrm{C}$ ). Такой многоэтапный подход с элементами ручной обработки и субъективного анализа позволил исключить из анализа нереально заниженные (или завышенные) значения нижней границы ВКС. 
Средние многолетние месячные параметры ВКС были получены с шагом $0,5^{\circ}$ по широте и долготе. При расчетах средних многолетних месячных статистических характеристик во всех квадратах (для нормирования вклада суточных и многосерийных станций) выполнялась следующая операция. Вначале в каждом квадрате проводилось осреднение всех данных, выполненных за конкретные сутки. Полученные средние за сутки значения в дальнейших расчетах климатических величин принимались с единичным вкладом. Эта процедура направлена на устранение влияния неравномерности вклада отдельных лет, что особенно важно для квадратов и горизонтов наблюдений с немногочисленным количеством исходных данных.

\section{Результаты и их обсуждение}

ВКС в Охотском море имеет минимальное вертикальное развитие с июня по сентябрь (рис. 1). В июне на преобладающей части моря нижняя граница ВКС не распространяется глубже 10 м. Только в динамически активных районах моря (банка Кашеварова, архипелаг Шантарских островов, проливы Курильской гряды и прилегающая к ним часть моря, а также зал. Шелихова) ВКС проникает до горизонтов 20-25 м.

В августе он распространяется до горизонтов 5-10 м. В то же время на входе в зал. Шелихова и в его восточной части нижняя граница ВКС заглубляется до горизонта 25 м (рис. 1). Незначительное вертикальное распространение ВКС в теплый период года обусловлено тем, что перенос тепла на нижележащие горизонты в Охотском море ограничивается плотностной стратификацией, связанной с прогревом и распреснением поверхностных вод. Более того, вертикальный обмен за счет ветро-волнового перемешивания также ослаблен, что является результатом большой повторяемости слабых ветров и штилевых ситуаций (Дашко, 1998).

В сентябре на большей части моря происходит незначительное (около 5 м) заглубление нижней границы ВКС. В то же время в динамически активных регионах моря (Шантарские острова, зал. Шелихова и мелководные проливы Курильской гряды) максимальные заглубления ВКС (до 20-25 м) сохраняются (рис. 1).

Следует отметить, что в теплый период года аномальное заглубление ВКС в районе банки Кашеварова и о. Ионы отчетливо выделяется только в июне (рис. 1).

Для мая и октября-ноября характерны переходные ситуации с более значительным (до 20-40 м) развитием вертикальной протяженности ВКС (рис. 1). В октябре и ноябре это связано с начинающимся охлаждением поверхностного слоя вод, а также с ростом скоростей ветра. Более значительное (чем летом) развитие ВКС в мае, вероятно, связано с межгодовой изменчивостью термической структуры вод моря. Поэтому при расчете нижней границы ВКС в массиве данных за май могут присутствовать океанографические данные двух типов, отражающие как зимнее, так и летнее состояние верхнего слоя вод. Для глубины расположения нижней границы ВКС в переходные периоды характерно наличие максимальных значений в зоне распространения трансформированных тихоокеанских вод, а также в динамически активных районах моря.

Как видно на рис. 1, максимального развития верхний квазиоднородный слой достигает в холодный период года (с декабря по апрель). Видно, что на преобладающей части моря, где нет ледяного покрова, его нижняя граница с декабря по февраль, как правило, не распространяется глубже 20-40 м. В марте-апреле происходит существенное заглубление нижней границы ВКС (до 60-80 м). В районе центральных и южных проливов Курильской гряды, а также в зоне перемещения трансформированных тихоокеанских вод выделяются области с максимальным развитием ВКС, где он достигает горизонтов 100-120 м.

Аномально близкое к поверхности моря положение нижней границы ВКС в феврале (рис. 1) можно объяснить следующими факторами. В суровые годы максимальная ледовитость (площадь моря, занятая льдом по отношению к общей площади моря) Охотского моря в феврале составляет 90-95 \%. В эти годы кромка льда располагается, как правило, на расстоянии 60 миль к западу от средней части Курильской гряды. Только в районе, располагающемся между проливами Крузенштерна и Четвертым 

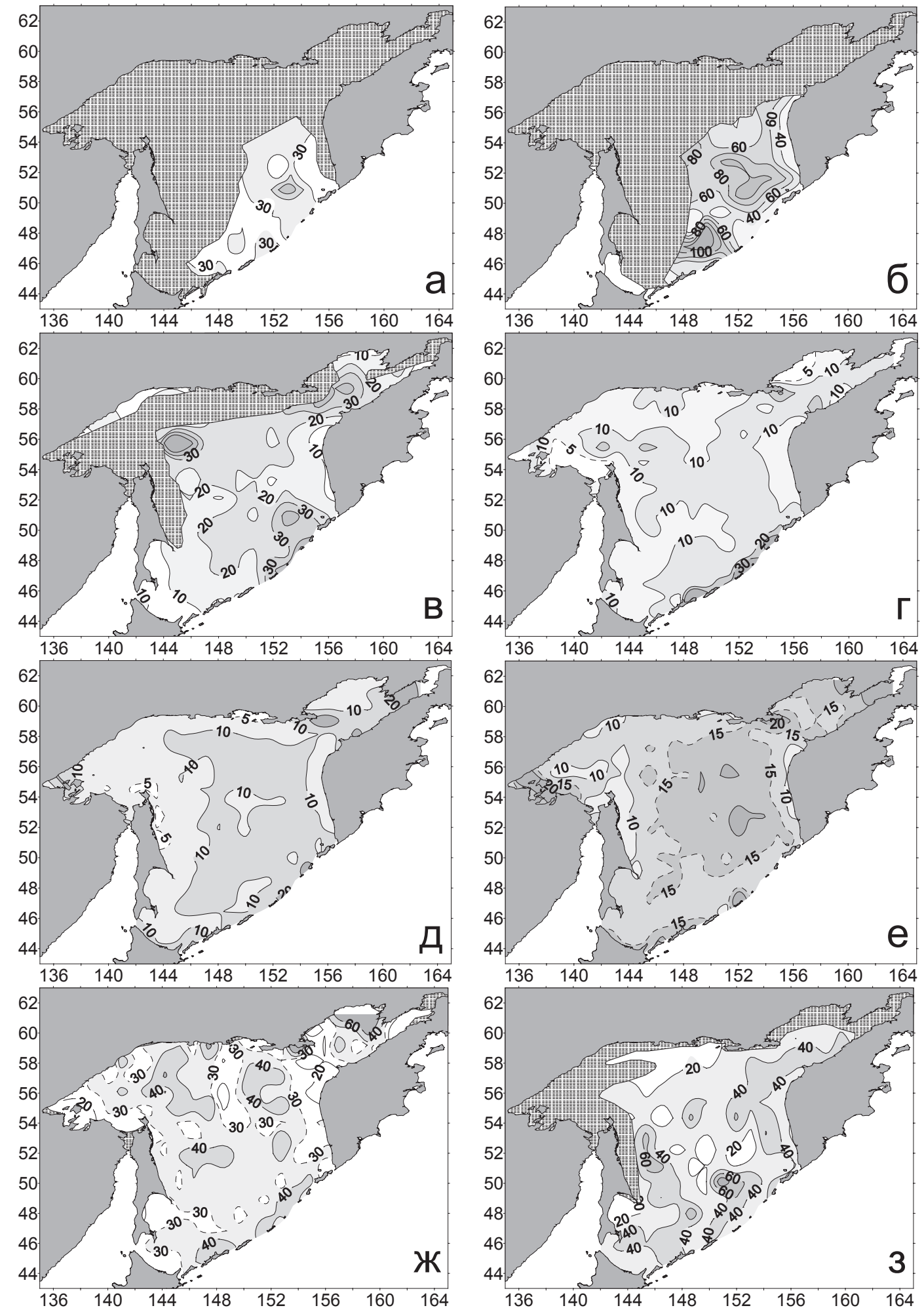

Рис. 1. Среднее многолетнее месячное положение нижней границы верхнего квазиоднородного слоя (м) в Охотском море: $\mathbf{a}$ - февраль; $\boldsymbol{\sigma}$ - апрель; в - май; г - июнь; д — август; е - сентябрь; ж - ноябрь; 3 - декабрь

Fig. 1. Mean mixed layer depth (m), by months: a — February; $\mathbf{\sigma}$ - April; в — May; $\mathbf{r}$ - June; д - August; $\mathbf{e}$ - September; ж — November; 3 - December 
Курильским, кромка льда удалена от гряды до 120 миль на север (Якунин, 2012). В феврале над свободной от льда поверхностью моря наблюдаются отрицательные значения температуры воздуха, велика вероятность штормовых ветров и обледенения судов (Дашко, 1998), что является серьезным препятствием для производства экспедиционных работ. Анализ имеющейся океанологической информации показал, что в «холодные» годы, если следовать классификации В.А. Лучина, И.А. Жигалова (2006), на свободной от льда акватории Охотского моря в феврале было выполнено только 43 океанологические станции (это около $3 \%$ от 1395 станций, выполненных в феврале). Следовательно, положение нижней границы ВКС в феврале, представленное на рис. 1 (a), отражает термическую структуру вод Охотского моря, характерную для «теплых» и «нормальных» лет.

По распределению максимальных значений (в поле изолиний глубины проникновения нижней границы ВКС) в холодный период года на свободной ото льда акватории моря выделяется перемещение трансформированных тихоокеанских вод от проливов северной и центральной частей Курильской гряды в направлении п-вов Кони и Пьягина, также вдоль материкового склона на северо-запад - к банке Кашеварова (рис. 1).

В поле температуры ВКС Охотского моря выделяются два существенно различающихся между собой типа пространственного распределения. Как видно на рис. 2, с декабря по апрель для ВКС характерно зимнее распределение температуры. Его главная особенность - это максимальные и положительные значения в проливах Курильской гряды (до $1{ }^{\circ} \mathrm{C}$ ), в водах течения Соя (у северных берегов о. Хоккайдо и южных островов Курильской гряды, где температура ВКС в декабре достигает $\left.3-4{ }^{\circ} \mathrm{C}\right)$, а также в зоне распространения трансформированных тихоокеанских вод, ядро которых (если следовать изотерме $0{ }^{\circ} \mathrm{C}$ ) хорошо согласуется с положением «восточного канала». В декабре на свободной ото льда поверхности моря по положительным значениям температуры в ВКС выделяется поток Срединного течения, которое отделяется от Западно-Камчатского течения на параллели $52^{\circ}$ с.ш. Сравнительно теплые воды Срединного течения (более $0{ }^{\circ} \mathrm{C}$ ) разделяют два ядра «холода» (терминология В.И. Чернявского (1992)): североохотское и локализующееся восточнее о. Сахалин.

С июня по сентябрь (рис. 2) в поле температуры ВКС выделяется летний тип пространственного распределения. Его отличительная черта - пониженные значения температуры в динамически активных зонах Охотского моря (проливы Курильской гряды, банка Кашеварова, вход в зал. Шелихова, Шантарский регион, северо-восточный шельф о. Сахалин), где отмечается интенсификация приливных и непериодических течений.

Отметим, что на формирование термической аномалии над северо-восточным шельфом о. Сахалин (помимо интенсификации приливных и непериодических течений) оказывает влияние также наличие прибрежного апвеллинга, под влиянием которого происходит подъем более холодных подповерхностных вод (Пищальник и др., 2014). Области с минимальными значениями температуры ВКС хорошо отражают существующую систему течений в море (Морошкин, 1966; Лучин, 1982, 1987). По ним выделяются поток трансформированных тихоокеанских вод у западной Камчатки, поток Восточно-Сахалинского течения, а также южная периферия циклонической циркуляции в зал. Шелихова.

Максимальные значения температуры ВКС в этот период года характерны для центральной, северо-западной и южной частей моря. В двух первых это связано с притоком солнечной радиации, слабыми ветрами над акваторией моря и удаленностью от динамически активных зон моря. В южной части моря, помимо вклада солнечной радиации, основное влияние на термическое состояние ВКС оказывает течение Соя, переносящее теплые воды из Японского моря.

В мае и октябре-ноябре наблюдаются промежуточные ситуации распределения температуры в ВКС. Наиболее высокая температура воды в эти периоды года, как и летом, отмечается в южной части моря и в районе южных проливов Курильской гряды, что определяется влиянием адвекции тихоокеанских вод и вод течения Соя из Японского моря (рис. 2). 

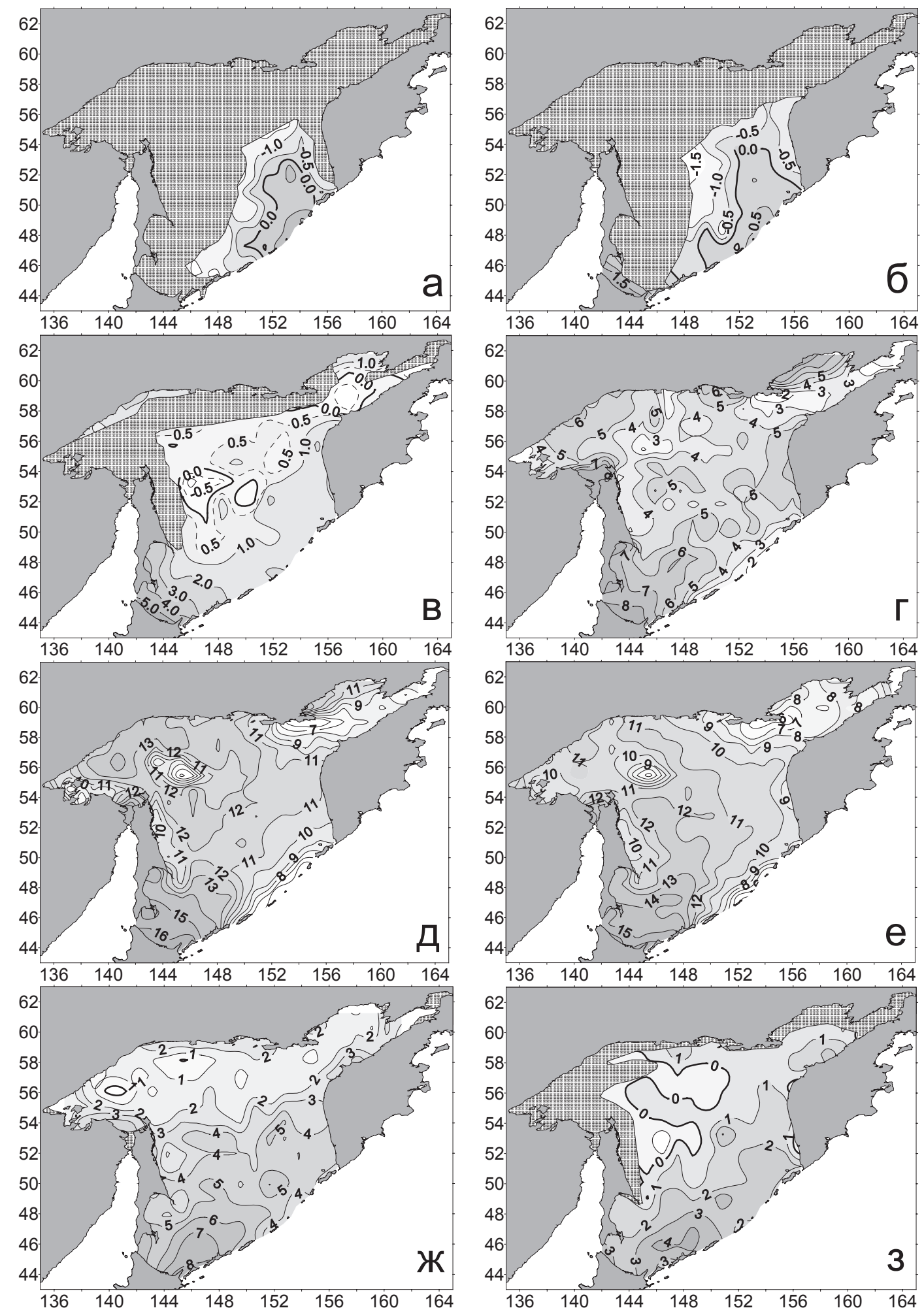

Рис. 2. Средняя многолетняя месячная температура воды $\left({ }^{\circ} \mathrm{C}\right)$ верхнего квазиоднородного слоя в Охотском море: $\mathbf{a}$ - февраль; $\boldsymbol{\sigma}$ - апрель; в - май; г — июнь; д - август; $\mathbf{e}-$ сентябрь; ж - ноябрь; 3 - декабрь

Fig. 2. Mean water temperature $\left({ }^{\circ} \mathrm{C}\right)$ within the mixed layer, by months: a - February; $\mathbf{\sigma}-$ April; в — May; г — June; д — August; e — September; ж — November; 3 — December 
В октябре-ноябре минимальные значения температуры в ВКС характерны для шельфа северной части моря (рис. 2), где невысокий теплозапас верхнего слоя вод и более низкая температура воздуха над морем. В октябре также происходит перестройка атмосферной циркуляции на зимний режим (Дашко, 1998), и на верхний слой вод начинает влиять перенос холодных воздушных масс с северных берегов Охотского моря. Это приводит к росту температурных градиентов на границе вода-воздух. За счет преобладания ветров северного направления на северной периферии моря в октябреноябре формируются прибрежные апвеллинги, вследствие которых непосредственно у берегов образуются области повышенных значений температуры в ВКС. В этот период (за счет притока более теплых речных вод в море) на акватории Шантарских островов и в Сахалинском заливе формируются локальные области с более высокой температурой в ВКС.

В мае на преобладающей части свободной ото льда акватории моря наблюдаются положительные значения температуры воды в ВКС (рис. 2). В основном это связано с адвекцией более теплых тихоокеанских вод. В это время поверхностный прогретый слой имеет минимальное вертикальное развитие. Поэтому в динамически активных зонах зал. Шелихова и банки Кашеварова выделяются области с отрицательными значениями температуры в ВКС. За счет интенсификации течений здесь происходит перемешивание прогревающихся поверхностных и остаточных зимних вод, приводящее к существенному, по сравнению с окружающими водами, понижению температуры воды в ВКС.

В центре моря (восточнее Сахалина) в мае также выделяется область с отрицательной температурой ВКС (рис. 2). Ее формирование обусловлено двумя факторами. Во-первых, в регионе к востоку от Сахалина сравнительно долго сохраняется ледяной покров, чему способствует циклоническая циркуляция вод в центральной части Охотского моря (Морошкин, 1966; Лучин, 1982, 1987), на западной периферии которой происходит вынос льдов из северо-западной части моря, поэтому температура воды на поверхности моря здесь долго сохраняет зимнее состояние. Во-вторых, потоки вод на южной и восточной перифериях этого циклонического круговорота препятствуют проникновению в этот район моря теплых тихоокеанских вод.

Средние многолетние месячные поля солености ВКС в течение года сохраняют свои крупномасштабные особенности (рис. 3) и являются хорошими индикаторами существующей системы течений и процессов в деятельном слое Охотского моря.

Максимальные значения солености выделяются в южной и юго-восточной частях Охотского моря (рис. 3). В южной части моря это связано с течением Соя, которое переносит высокосоленые воды Японского моря у северных берегов о. Хоккайдо. Поступление вод через прол. Лаперуза, как следует из работы Савельева с соавторами (Saveliev et al., 2002), подвержено существенной сезонной изменчивости (максимальный приток высокосоленых вод из Японского моря в Охотское наблюдается в августе $(1,18$ $\mathrm{Sv})$, а минимальный — в декабре-феврале - 0,04 Sv). Поэтому с ноября по январь (период с отсутствием ледяного покрова в этой части моря), за счет существенного снижения поступления вод из Японского моря через прол. Лаперуза, в крайней южной части моря происходит понижение солености до 32,0-32,6 \%о.

В холодный период года (за счет перестройки атмосферной циркуляции над Охотским морем на зимний режим (Дашко, 1998)) происходит также интенсификация Восточно-Сахалинского течения, которое переносит распресненные воды на юг (Пищальник и др., 2014). Поэтому эти два фактора (интенсификация Восточно-Сахалинского течения и существенное снижение расходов в прол. Лаперуза) являются основной причиной отсутствия области с аномально высокой соленостью у северных берегов о. Хоккайдо и южных островов Курильской гряды с ноября по январь (рис. 3).

По повышенным значениям в полях солености (более 32,8-33,0 \%о зимой и 32,5 \%о летом) отчетливо проявляется перемещение трансформированных тихоокеанских вод в пределах Охотского моря Западно-Камчатским течением, переносящим высокосоленые воды на север в направлении п-овов Кони и Пьягина, а также Срединным течением, следующим в направлении банки Кашеварова (рис. 3). 

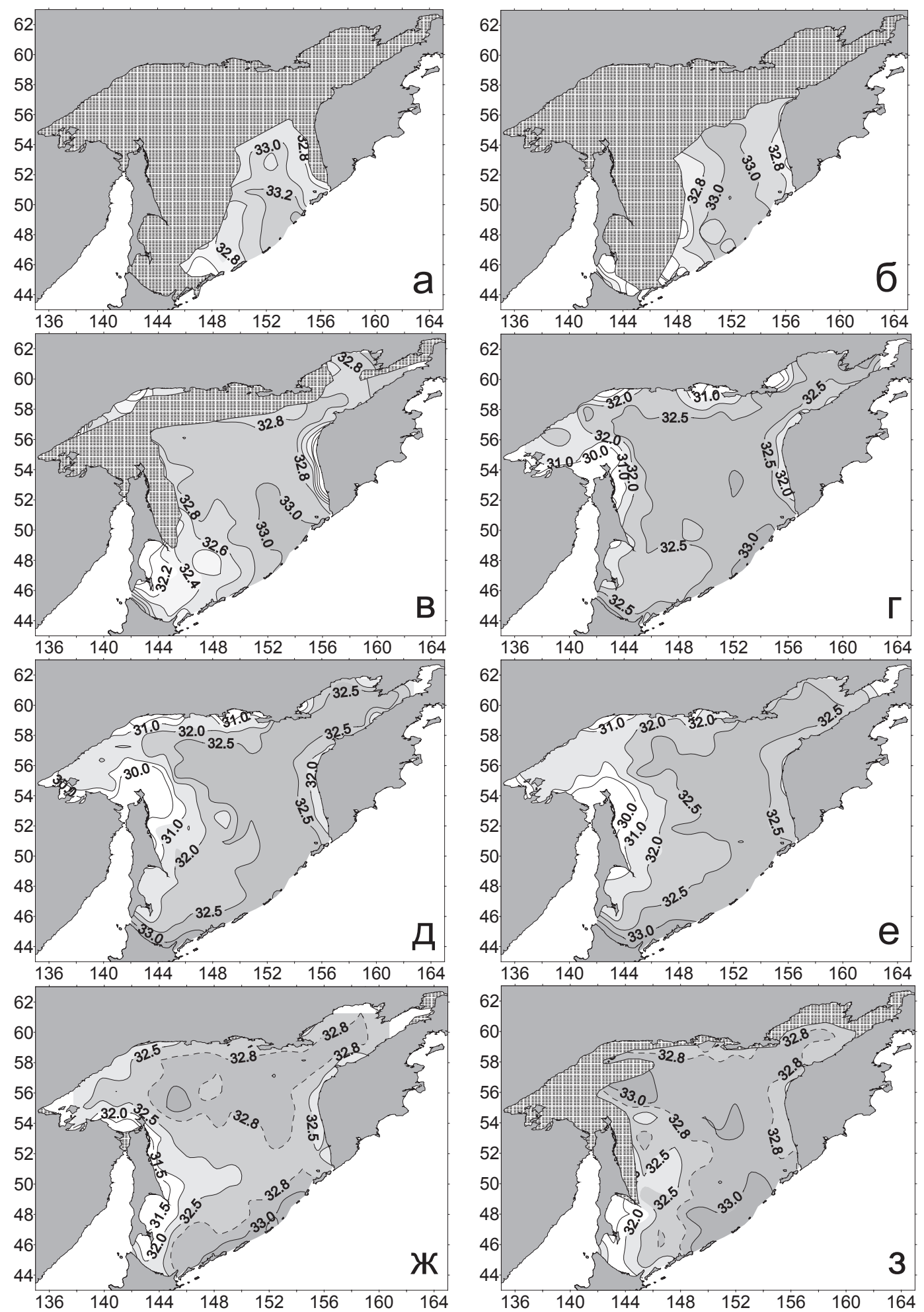

Рис. 3. Средняя многолетняя месячная соленость воды (\%) верхнего квазиоднородного слоя в Охотском море: $\mathbf{a}$ - февраль; $\boldsymbol{\sigma}$ - апрель; в - май; г - июнь; д- август; $\mathbf{e}-$ сентябрь; ж - ноябрь; з - декабрь

Fig. 3. Mean salinity (\%) within the mixed layer, by months: a — February; $\mathbf{\sigma}$ - April; B May; г — June; д — August; $\mathbf{e}$ - September; ж —-November; 3 - December 
Следует отметить, что динамически активные зоны Охотского моря (проливы Курильской гряды, вход в зал. Шелихова, архипелаг Шантарских островов) в полях солености ВКС, в отличие от полей температуры, не выделяются. Исключением является район над банкой Кашеварова, где (вследствие интенсификации вертикального обмена) в мае и ноябре-декабре формируются локальные области с соленостью на 0,2 \% выше по отношению к прилегающим водам.

На периферийных участках моря (исключая регион Курильской островной дуги) по распределению солености в ВКС в течение всего года выделяются прибрежные зоны опреснения (рис. 3), которые формируются под влиянием стока рек. Наиболее значительное влияние на режим солености верхнего слоя вод оказывает сток р. Амур. С июня по ноябрь, когда западная часть моря свободна от льда, зона опреснения (если следовать изолиниям солености в ВКС менее 31-32 \%о) может распространяться до параллели $56^{\circ}$ с.ш. к северу от Сахалинского залива. Зона распреснения также занимает шельф и склон восточного Сахалина и достигает о. Хоккайдо на юге (рис. 3). В северозападной части моря, как видно на рис. 3, эта обширная зона опреснения достигает максимального развития с июля по сентябрь (период с максимальными значениями стока р. Амур).

Область распреснения, связанная со стоком р. Амур, также хорошо согласуется с существующей схемой течений в центральной и южной частях Охотского моря. Как известно (Морошкин, 1966; Лучин, 1982, 1987), над Курильской котловиной существует антициклонический круговорот, на северной периферии которого происходит перенос вод на восток и северо-восток. Этот поток одновременно является и южной периферией циклонического круговорота в центральной части Охотского моря. Если следовать конфигурации изолиний в диапазоне 32,0-32,8 \%о, то представленные на рис. 3 поля солености в ВКС хорошо согласуются с особенностями системы течений в этой части Охотского моря.

Максимальное распреснение поверхностных вод наблюдается в августе и сентябре (рис. 3). В августе-сентябре траектории значительного числа тропических циклонов проходят через южную часть Дальнего Востока, поэтому на исследуемую акваторию и прилегающую часть суши выпадают обильные осадки, распресняющие верхний слой моря.

В октябре возрастает скорость ветра (по сравнению с летним периодом примерно в 2 раза), понижается температура воздуха (в северной части моря до $0-2{ }^{\circ} \mathrm{C}$, в южной до $8-12^{\circ} \mathrm{C}$ ). В результате поверхностные воды охлаждаются, начинается термическая конвекция, и соленость в ВКС Охотского моря вновь начинает расти (рис. 3).

\section{Выводы}

Использование наиболее полного массива глубоководной океанографической информации (111 944 станции за период с 1931 по 2014 г.) позволило представить детальные средние многолетние месячные поля параметров ВКС в Охотском море.

Получено, что нижняя граница ВКС в Охотском море с июня по октябрь не выходит за пределы 5-25 м (с максимумами в динамически активных районах моря). Максимального развития ВКС достигает в период с декабря по апрель. Его нижняя граница в этот период года, как правило, не распространяется глубже 40-60 м, но в районе центральных проливов Курильской гряды и в зоне перемещения трансформированных тихоокеанских вод она заглубляется до 100-120 м.

В поле температуры ВКС Охотского моря выделяются два существенно различающихся между собой типа пространственного распределения. С декабря по апрель для ВКС характерно зимнее распределение температуры. Его главная особенность - это максимальные и положительные значения в проливах Курильской гряды (до $\left.1{ }^{\circ} \mathrm{C}\right)$, в водах течения Соя (у северных берегов о. Хоккайдо и южных островов Курильской гряды, где температура ВКС в декабре достигает 3-4 $\left.{ }^{\circ} \mathrm{C}\right)$, а также в зоне распространения трансформированных тихоокеанских вод, ядро которых (если следовать изотерме $0{ }^{\circ} \mathrm{C}$ ) хорошо согласуется с положением «восточного канала». 
С июня по сентябрь в поле температуры ВКС выделяется летний тип пространственного распределения. Его отличительная черта - пониженные значения температуры в динамически активных зонах Охотского моря (проливы Курильской гряды, банка Кашеварова, вход в зал. Шелихова, Шантарский регион, северо-восточный шельф о. Сахалин), где отмечается интенсификация приливных и непериодических течений.

В мае и октябре-ноябре наблюдаются промежуточные ситуации распределения температуры в ВКС. Наиболее высокая температура воды в эти периоды года, как и летом, отмечается в южной части моря и в районе южных проливов Курильской гряды, что определяется влиянием адвекции тихоокеанских вод и вод течения Соя из Японского моря. В октябре-ноябре минимальные значения температуры в ВКС характерны для шельфа северной части моря. За счет преобладания ветров северного направления на северной периферии моря в октябре-ноябре формируются прибрежные апвеллинги с повышенными значениями температуры в ВКС. За счет притока более теплых речных вод в море на акватории Шантарских островов и в Сахалинском заливе формируются локальные области с более высокой температурой в ВКС.

Средние многолетние месячные поля солености ВКС в течение года сохраняют свои крупномасштабные особенности и являются хорошими индикаторами существующей системы течений и процессов в деятельном слое Охотского моря. Максимальные значения солености выделяются в южной и юго-восточной частях Охотского моря. На периферийных участках моря (исключая регион Курильской островной дуги) по распределению солености в ВКС в течение всего года выделяются прибрежные зоны распреснения, которые формируются под влиянием стока рек. Наиболее значительное влияние на режим солености верхнего слоя вод оказывает сток р. Амур.

\section{Список литературы}

Ванин Н.С. Сравнительный анализ динамики вод и прогрева верхнего слоя в сахалинокурильском районе в 1997 и 2000 гг. // Изв. ТИНРО. — 2002. - Т. 130. — С. 59-70.

Гершанович Д.Е., Муромцев А.М. Океанологические основы биологической продуктивности Мирового океана : моногр. - Л. : Гидрометеоиздат, 1982. - 320 с.

Дашко Н.А. Метеорологический режим // Гидрометеорология и гидрохимия морей. - СПб. : Гидрометеоиздат, 1998. - Т. 9 : Охотское море, вып. 1 : Гидрометеорологические условия. - С. 25-75.

Дулепова Е.П. Экосистемные исследования ТИНРО-центра в дальневосточных морях // Изв. ТИНРО. - 2005. - Т. 141. — С. 3-29.

Леонов А.К. Региональная океанография. Ч. 1. Берингово, Охотское, Японское, Каспийское, Черное моря : моногр. - Л. : Гидрометеоиздат, 1960. — 766 с.

Лучин В.А. Диагностический расчет циркуляции вод Охотского моря в летний период // Тр. ДВНИГМИ. - 1982. - Вып. 96. - С. 69-77.

Лучин В.А. Циркуляция вод Охотского моря и особенности ее внутригодовой изменчивости по результатам диагностических расчетов // Тр. ДВНИГМИ. - 1987. - Вып. 36. - С. 3-13.

Лучин В.А., Жигалов И.А. Межгодовые изменения типовых распределений температуры воды в деятельном слое Охотского моря и возможность их прогноза // Изв. ТИНРО. - 2006. — Т. 147. - C. 183-204.

Лучин В.А., Лаврентьев В.М. Водные массы Охотского моря // Гидрометеорология и гидрохимия морей. - СПб. : Гидрометеоиздат, 1998. - Т. 9 : Охотское море, вып. 1 : Гидрометеорологические условия. - С. 166-174.

Морошкин К.В. Водные массы Охотского моря : моногр. - М. : Наука, 1966. - 68 с.

Пищальник В.М., Архипкин В.С., Леонов А.В. Восстановление годового хода термохалинных характеристик и циркуляции вод на северо-восточном шельфе Сахалина // Водные ресурсы. — 2014. — Т. 41, № 4. - С. 362-374. DOI: 10.7868/S0321059614040129.

Радченко В.И., Мельников И.В., Волков А.Ф. и др. Условия среды, состав планктона и нектона эпипелагиали южной части Охотского моря и сопредельных океанских вод летом // Биол. моря. - 1997. - Т. 23, № 1. - С. 15-25.

Ушаков П.В. Система вертикальных зон Охотского моря // ДАН СССР. — 1949. — Т. 68, № 4. - С. 769-772.

Хен Г.В., Ванин Н.С., Фигуркин А.Л. Особенности гидрологических условий в северной части Охотского моря во второй половине 90-х гг. // Изв. ТИНРО. — 2002. — Т. 130. — С. $24-43$. 
Чернявский В.И. Изменчивость ядра холода и прогноз типа термического режима на севере Охотского моря // Океанологические основы биологической продуктивности северо-западной части Тихого океана. - Владивосток, 1992. — С. 104-113.

Шунтов В.П. Биология дальневосточных морей России : моногр. - Владивосток : ТИНРО-центр, 2016. — Т. 2. - 604 с.

Шунтов В.П. Состояние изученности многолетних циклических изменений численности рыб дальневосточных морей // Биол. моря. — 1986. - Т. 12, № 3. - С. 3-14.

Якунин Л.П. Атлас основных параметров ледяного покрова Охотского моря. - Владивосток : Издат. дом Дальневост. федерал. ун-та, 2012. - 118 с.

Dong S., Sprintall J., Gille S.T., Talley L. Southern Ocean mixed-layer depth from Argo float profiles // J. Geophys. Res. — 2008. — Vol. 113. - P. C06013. DOI: 10.1029/2006JC004051.

D'Ortenzio F., Iudicone D., de Boyer Montegut C. et al. Seasonal variability of the mixed layer depth in the Mediterranean Sea as derived from in situ profiles // Geophys. Res. Lett. - 2005. — Vol. 32, Iss. 12. - P. L12605. DOI: 10.1029/2005GL022463.

Falkowski P.G., Barber R.T., Smetacek V. Biogeochemical controls and feedbacks on ocean primary production // Science. — 1998. — Vol. 281, Iss. 5374. — P. 200-206. DOI: 10.1126/science.281.5374.200.

Holte J., Talley L. A new algorithm for finding mixed layer depths with applications to Argo data and subantarctic mode water formation // J. Atm. Oceanic Techn. — 2009. — Vol. 26. — P. 1920-1939. DOI: 10.1175/2009JTECHO543.1.

Jang C.J., Park J., Park T., Yoo S. Response of the ocean mixed layer depth to global warming and its impact on primary production: a case for the North Pacific Ocean // ICES J. Mar. Sci. — 2011. — Vol. 68, Iss. 6. — P. 996-1007. DOI: 10.1093/icesjms/fsr064.

Jo C.O., Lee J.-Y., Park K.-A. et al. Asian dust initiated early spring bloom in the northern East/ Japan Sea // Geophys. Res. Lett. — 2007. — Vol. 34, Iss. 5. — P. L05602. DOI: 10.1029/2006GL027395.

Kara A.B., Rochford P.A., Hurlburt H.E. An optimal definition for ocean mixed layer depth // J. Geophys. Res. — 2000. — Vol. 105, № C7. — P. 16,803-16,821. DOI: 10.1029/2000JC900072.

Kitani K. An oceanographic study of the Okhotsk Sea - particularly in regard to cold waters // Bull. Far Seas Fish. Res. Lab. - 1973. - Vol. 9. - P. 45-77.

Lorbacher K., Dommenget D., Niiler P.P., Köhl A. Ocean mixed layer depth: a subsurface proxy of ocean-atmosphere variability // J. Geophys. Res. — 2006. — Vol. 111, № C7. — P. C07010. DOI: $10.1029 / 2003 J C 002157$.

Oh D.-C., Park M.-K., Choi S.-H. et al. The air-sea exchange of $\mathrm{CO}_{2}$ in the East Sea (Japan Sea) // J. Oceanogr. - 1999. - Vol. 55, Iss. 2. - P. 157-169.

Ohno Y., Kobayashi T., Iwasaka N., Suga T. The mixed layer depth in the North Pacific as detected by the Argo floats // Geophys. Res. Lett. — 2004. — Vol. 31, Iss. 11. - P. L11306. DOI: 10.1029/2004GL019576.

Oka E., Talley L.D., Suga T. Temporal variability of winter mixed layer in the mid- to highlatitude North Pacific // J. Oceanogr. — 2007. — Vol. 63, Iss. 2. - P. 293-307. DOI: 10.1007/ s10872-007-0029-2.

Saveliev A.V., Danchenkov M.A., Hong G.-H. Volume Transport through the La-Perouse (Soya) Strait between the East Sea (Sea of Japan) and the Sea of Okhotsk // Ocean and Polar Research. 2002. - Vol. 24, № 2. - P. 147-152. DOI: 10.4217/OPR.2002.24.2.147.

Thomson R.E., Fine I.V. Estimating mixed layer depth from oceanic profile data // J. Atm. Oceanic. Techn. - 2003. - Vol. 20. - P. 319-329.

Yamada K., Ishizaka J., Yoo S. et al. Seasonal and interannual variability of sea surface chlorophyll a concentration in the Japan/East Sea (JES) // Prog. Oceanogr. — 2004. — Vol. 61, Iss. 2-4. - P. 193-211. DOI: 10.1016/j.pocean.2004.06.001.

\section{References}

Vanin, N.S., Comparative analysis of dynamics and heating of the surface layer in SakhalinKuril region in 1997 and 2000, Izv. Tikhookean. Nauchno-Issled. Inst. Rybn. Khoz. Okeanogr., 2002, vol. 130, pp. 59-70.

Gershanovich, D.E. and Muromtsev, A.M., Okeanologicheskie osnovy biologicheskoi produktivnosti Mirovogo okeana (Oceanological Bases of the Biological Productivity of the World Ocean), Leningrad: Gidrometeoizdat, 1982.

Dashko, N.A., Meteorological regime, in Gidrometeorologiya i gidrokhimiya morei. T. 9: Okhotskoye more (Hydrometeorology and Hydrochemistry of Seas, vol 9: Sea of Okhotsk), St. Petersburg: Gidrometeoizdat, 1998, issue 1, pp. 25-75. 
Dulepova, E.P., Ecosystem researches of TINRO-Center in the Far Eastern Seas, Izv. Tikhookean. Nauchno-Issled. Inst. Rybn. Khoz. Okeanogr., 2005, vol. 141, pp. 3-29.

Leonov, A.K., Regional'naya okeanografiya. Ch. 1. Beringovo, Okhotskoe, Yaponskoe, Kaspiiskoe, Chernoe morya (Regional Oceanography, part 1: Bering Sea, Sea of Okhotsk, Sea of Japan, Caspian Sea, and Black Sea), Leningrad: Gidrometeoizdat, 1960.

Luchin, V.A., Diagnostic calculation of water circulation in the Sea of Okhotsk in summer, $T r$. Dal'nevost. Nauchno-Issled. Gidrometeorol. Inst., 1982, no. 96, pp. 69-77.

Luchin, V.A., Water circulation in the Sea of Okhotsk and patterns of its intra-annual variations as inferred from the results of diagnostic calculations, Tr. Dal'nevost. Nauchno-Issled. Gidrometeorol. Inst., 1987, no. 36, pp. 3-13.

Luchin, V.A. and Zhigalov, I.A., Types of water temperature distribution in active layer of the Okhotsk Sea and possibility of its prediction, Izv. Tikhookean. Nauchno-Issled. Inst. Rybn. Khoz. Okeanogr., 2006, vol. 147, pp. 183-204.

Luchin, V.A. and Lavrentyev, V.M., Water masses of the Sea of Okhotsk, in Gidrometeorologiya i gidrokhimiya morei. T. 9: Okhotskoye more (Hydrometeorology and Hydrochemistry of Seas, vol 9: Sea of Okhotsk), St. Petersburg: Gidrometeoizdat, 1998, issue 1, pp. 166-174.

Moroshkin, K.V., Vodnye massy Okhotskogo morya (Water Masses of the Sea of Okhotsk), Moscow: Nauka, 1966.

Pishchal'nik, V.M., Arkhipkin, V.S., and Leonov, A.V., Reconstruction of the annual variations of thermohaline characteristics and water circulation on the northeastern Sakhalin Shelf, Water Resour., 2014, vol. 41, no. 4, pp. 385-395. doi https://doi.org/10.1134/S0097807814040113

Radchenko, V.I., Mel'nikov, I.V., Volkov, A.F., Semenchenko, A.Yu., Glebov, I.I., and Mikheev, A.A., Environmental conditions and composition of plankton and nekton in epipelagic layer of the southern Sea of Okhotsk and adjacent Pacific waters in summer, Russ. J. Mar. Biol., 1997, vol. 23, no. 1, pp. 13-25.

Ushakov, P.V., The system of vertical zones in the Sea of Okhotsk, Dokl. Akad. Nauk SSSR, 1949, vol. 68, no. 4, pp. 769-772.

Khen, G.V., Vanin, N.S., and Figurkin, A.L., Peculiarity of the hydrological conditions in the northern part of the Okhotsk Sea in the second half of 90s, Izv. Tikhookean. Nauchno-Issled. Inst. Rybn. Khoz. Okeanogr., 2002, vol. 130, pp. 24-43.

Chernyavskii, V.I., Variability of the cold core and prediction of the type of thermal regime in the north of the Sea of Okhotsk, Okeanologicheskie osnovy biologicheskoi produktivnosti severozapadnoi chasti Tikhogo okeana (Oceanological Bases of Biological Productivity of the Northwestern Pacific Ocean), Vladivostok: TINRO, 1992, pp. 104-113.

Shuntov, V.P., Biologiya dal'nevostochnykh morei Rossii (Biology of the Far Eastern Seas of Russia), Vladivostok: TINRO-Tsentr, 2016, vol. 2.

Shuntov, V.P., The present state of knowledge of long-term cyclical fluctuations in the abundance of fish in seas of the Far East, Sov. J. Mar. Biol., 1986, vol. 12, no. 3, pp. 127-137.

Yakunin, L.P., Atlas osnovnykh parametrov ledyanogo pokrova Okhotskogo morya (Atlas of the Main Parameters of the Ice Cover in the Sea of Okhotsk), Vladivostok: Izd. Dom Dal'nevost. Fed. Univ., 2012.

Dong, S., Sprintall, J., Gille, S.T., and Talley, L., Southern Ocean mixed-layer depth from Argo float profiles, J. Geophys. Res., 2008, vol. 113, pp. C06013. doi 10.1029/2006JC004051

D'Ortenzio, F., Iudicone, D., de Boyer Montegut, C., Testor, P., Antoine, D., Marullo, S., Santoleri, R., and Madec, G., Seasonal variability of the mixed layer depth in the Mediterranean Sea as derived from in situ profiles, Geophys. Res. Lett., 2005, vol. 32, no. 12, pp. L12605. doi 10.1029/2005GL022463

Falkowski, P.G., Barber, R.T., and Smetacek, V., Biogeochemical controls and feedbacks on ocean primary production, Science, 1998, vol. 281, no. 5374, pp. 200-206. doi 10.1126/science.281.5374.200

Holte, J. and Talley, L., A new algorithm for finding mixed layer depths with applications to Argo data and subantarctic mode water formation, J. Atmos. Oceanic Technol., 2009, vol. 26, pp. 1920-1939. doi 10.1175/2009JTECHO543.1

Jang, C.J., Park, J., Park, T., and Yoo, S., Response of the ocean mixed layer depth to global warming and its impact on primary production: a case for the North Pacific Ocean, ICES J. Mar. Sci., 2011, vol. 68, no. 6, pp. 996-1007. doi 10.1093/icesjms/fsr064

Jo, C.O., Lee, J.-Y., Park, K.-A., Kim, Y.H., and Kim, K.-R., Asian dust initiated early spring bloom in the northern East/Japan Sea, Geophys. Res. Lett., 2007, vol. 34, no. 5, pp. L05602. doi 10.1029/2006GL027395

Kara, A.B., Rochford, P.A., and Hurlburt, H.E., An optimal definition for ocean mixed layer depth, J. Geophys. Res., 2000, vol. 105, no. C7, pp. 16 803-16 821. doi 10.1029/2000JC900072 
Kitani, K., An oceanographic study of the Okhotsk Sea - particularly in regard to cold waters, Bull. Far Seas Fish. Res. Lab., 1973, vol. 9, pp. 45-77.

Lorbacher, K., Dommenget, D., Niiler, P.P., and Köhl, A., Ocean mixed layer depth: a subsurface proxy of ocean-atmosphere variability, J. Geophys. Res., 2006, vol. 111, no. C7, pp. C07010. doi 10.1029/2003JC002157

Oh, D.-C., Park, M.-K., Choi, S.-H., Kang, D.-J., Park, S.Y., Hwang, J.S., Andreev, A., Hong, G.H., and Kim, K.-R., The air-sea exchange of $\mathrm{CO}_{2}$ in the East Sea (Japan Sea), J. Oceanogr., 1999, vol. 55, no. 2, pp. 157-169.

Ohno, Y., Kobayashi, T., Iwasaka, N., and Suga, T., The mixed layer depth in the North Pacific as detected by the Argo floats, Geophys. Res. Lett., 2004, vol. 31, no. 11, pp. L11306. doi 10.1029/2004GL019576

Oka, E., Talley, L.D., and Suga, T., Temporal variability of winter mixed layer in the mid- to high-latitude North Pacific, J. Oceanogr., 2007, vol. 63, no. 2, pp. 293-307. doi 10.1007/s10872007-0029-2

Saveliev, A.V., Danchenkov, M.A., and Hong, G.-H., Volume transport through the La-Perouse (Soya) Strait between the East Sea (Sea of Japan) and the Sea of Okhotsk, Ocean Polar Res., 2002, vol. 24, no. 2, pp. 147-152. doi 10.4217/OPR.2002.24.2.147

Thomson, R.E. and Fine, I.V., Estimating mixed layer depth from oceanic profile data, $J$. Atmos. Oceanic Technol., 2003, vol. 20, pp. 319-329.

Yamada, K., Ishizaka, J., Yoo, S., Kim, H.-C., and Chiba, S., Seasonal and interannual variability of sea surface chlorophyll a concentration in the Japan/East Sea (JES), Prog. Oceanogr., 2004, vol. 61, nos. 2-4, pp. 193-211. doi 10.1016/j.pocean.2004.06.001

Поступила в редакиию 5.10.2018 2. После доработки 11.10.2018 г. Принята к публикаџии 11.10.18 2. 